\title{
ROLE AND IMPORTANCE OF THE PLAYING SPACE IN PSYCHIC DEVELOPMENT OF A PRE-SCHOOL CHILD
}

\author{
Oksana Bondar \\ Department of Psychology and Social Work \\ Vinnytsia State Pedagogical University named after Mykhailo Kotsiubynsky \\ 32 Ostrozkogo str., Vinnytsia, Ukraine, 21001 \\ bondar.research@gmail.com
}

\section{Abstract}

In the research process it has been determined, that the full-value development of a preschool child takes place at the expanse of high-quality organization and effective use of the playing space. It has been outlined, that high-quality organization of the playing space favors the harmonic combination of psychic, physical and spiritual development of a child. The conducted theoretical analysis allowed to separate four main components that must be taken into account in the process of organizing the high-quality playing space of pre-school children, namely: content, material, organizational and personal. It has been noted, that a structural model of the qualitatively organized playing space of a pre-school child is based on acknowledgement of the child-centered orientation priority. It has been proved, that the agreed combination of four components of the playing space provides psychological safety of a pre-school child and favors the high level development of its cooperation in the process of interaction with others. It has been revealed, that the content of realized playing actions, material filling of the playing space, its dynamics and mobility, inclusion of all children in the active playing activity need essentially other approaches. There have been fixed contradictions between necessary and real ideas of teachers as to the organization quality of the playing space for pre-school children.

The problem of quality organization of the playing space for pre-school children gains spee cial importance under conditions of modern society that dictates new rules and requirements to the development of a successful person. The formation of the high level ability to understand own possibilities, to reveal initiative and comprehensively realize themselves in pre-school children provides the presence and interconnection of all structural components of the playing space.

Keywords: playing environment, playing activity, organization quality, child-centered directionality, life competence.

DOI: $10.21303 / 2504-5571.2020 .001539$

\section{Introduction}

Consideration of the problem of organization and influence of the playing space on psychic development of a pre-school child is conditioned by the intensive attention of society to the formation of its value orientations, resistance to negative social influences, self-revelation, self-realization and self-statement under conditions of interpersonal relation. The emergence of modern advanced technologies, allowing a pre-school child to realize a series of social functions, without entering a personal interaction, negatively influences its psychic development and results in disorders of the individualization and integration process; disharmony in physical (conduct, actions), emotional (emotional manifestations, desires) and mental (ideas, judgments) dimensions of child life. The absence of integrity in pre-school child's emotional and mental system functioning may result in non-formation of the life competence, unsuccessful realization of any forms of activity and absence of a quality activity level in reaction to negative social influences. A pre-school child may become an active subject of own life activity only under conditions of the developing playing space. The age potential of a pre-school child cannot be realized beyond it. The playing space is an important factor of pre-school child's psychic development and a necessary condition for forming its life competence.

Changes, taking place today throughout the world and especially in Ukraine, essentially influence the child life space, determine the specificity of its activity and find their reflection in its 
psychic development. The influence of social transformations on the content of child's activity and communication actualizes the problem of studying quality and quantity characteristics of its psychic development. As far as age with inherent initial socialization, inclusion in the world of culture and common human values, formation of relations with representatives of other social life spheres is an important stage in child psychic development, we pay special attention to the activity of preschool children. Acquisition of the life competence, practical mastering of the system of knowledge about oneself and environment, formation of moral values, development of skills to use acquired information in the practical life activity depends on pre-school child's inclusion in different types of playing activity. Cognitive activity intensification and psychic development of a pre-school child are mainly determined by the level of its inclusion in the playing process, which content and specificity depend on playing space organization peculiarities. So, the full-value psychic development of a pre-school child depends on playing space quality. The qualitatively organized playing space has a principal importance for pre-school child's psychic development, because it is grounded on its age and individual peculiarities.

Psychological-pedagogical theories and practices, dealing with pre-school child's psychic development, acknowledge the first-turn importance of the problem of playing space influence on it $[1,2]$. The problem of subject-developing environment of a child is presented in works of foreign and native scientists $[3,4]$.

The researcher N. Kaschuk [5] states that in the process of child playing space organization, special attention must be paid to the principle of activity, emotional comfort and connection with real life. According to O. Kononko [6], own "Me" of a child must be in the center of the developing playing space. G. Lavrentieva [7] accents the correspondence of the subject-playing environment to child's age peculiarities and functional possibilities with an insufficient exceed of complication level. The famous psychologist V. Petrovsky [8] offers to observe principles of the complex approach and free centering at organizing the child developing-playing space. R. Shteiner [9] considers the playing space of a pre-school child through the "physical environment", giving an effective place to a developing toy. He thinks that a child need toys, made by own hands of natural materials, but not logically "produced by the intellectual civilization". The American researcher of the child playing space Frost [10] pays attention to the complex approach in creating the paying environment and an important role of adults in attracting children to world cognition by playing. O. Kononko [11] unp derlines that the system of needs forms in the pre-school age through the external environment that stimulates the cognitive process in a child at playing. Native researchers of pre-school children's development I. Karabaeva [12], I. Bekh [13], K. Karasyova [14, 15] accent that playing activity forms basic qualities of a person, and playing space quality organization gives a child a possibility to pass at a higher level of psychic development.

So, despite the fact that there are a lot of scientific works, devoted to peculiarities of pre-school child's playing space organization, psychologists continue to search for such playing environment that would provide the full-value psychic development and favor the maximal enrichment of the content of forms of child activity through communication between themselves and with adults.

The aim of the scientific study is to disclose the role and importance of the playing space in psychic development of a modern pre-school child.

\section{Research methods}

The scientific search was based on using theoretical methods, namely psychological analysis of the problem of pre-school child's playing space quality organization, system analysis and generalization of theoretical-methodological approaches to questions, connected with the content, material, organizational and personal components of the playing space. The playing space quality was estimated by the method of observation over pre-school children's and pre-school teachers' activity.

\section{Results and discussions}

Today there is an urgent necessity to study the quality organization of the-school child's playing space for providing its effective influence on its psychological development. It is connected 
with the fact that pre-school children's playing activity is more and more often considered by adults as an attraction, as a type of leisure that purposeful studying, which result, according to parents, is mastering of concrete skills may successfully oppose to. Adults, especially parents, more and more re-orient on learning of pre-school children. Achievements in the sphere of education and growth of the priority of learning types of activity oust the playing one more and more. The essential number of parents considers learning of a pre-school child more important and useful child's activity than the playing one. The priority of knowledge and the learning process oust the playing activity from the living environment of a modern pre-school child. At that, a typical phenomenon of preschool child's life activity became so-called "childhood marketization" that is toys transform from a playing means to a commodity, bought by adults for their children. Modern psychological studies demonstrated that more than 200 toys are in the child's playing space, of which a child uses only $5 \%$, and children better concentrate and play longer with a less number of toys $[16,17]$. Toys transh form from stimulators of pre-school child's external and internal activity in a qualitatively, filling its physical space. The playing activity deficit in the qualitatively organized playing space results in the complex of problems in modern pre-school child's development. The absence or primitive level of playing space organization results in the development deformation of key personal constructions of a pre-school child. Just that is why it is important to study the role and meaning of the playing space in pre-school child's psychic development.

In wide sense, playing space is a socio-cultural environment of a pre-school child, providing the integrity of social and natural means for supporting diverse activities, favoring the full-value psychic development of a pre-school child. The modern playing space must be based on a new approach to its organization, which defines the personally-oriented directionality as a priority in the conception of pre-school child's psychic development. The quality pre-school child's playing space organization, must be based on multifunctionalism of the environment and playing materials that essentially stimulate creation of playing ideas. At the same time the playing environment and toys with a fixed type of effect provoke stereotype and uniform ways of pre-school child's actions. So, the level of pre-school child's playing activity essentially depends on playing space organization quality. In situations, where a pre-school child can change own playing space independently using subjects-substitutes and other filling and assistant materials, the playing activity level is essentially higher.

Playing space must be considered as a generalized image of situations, created for manifesting pre-school child's independent actions, its cognitive, practical and creative activity. Effective forms of playing space organization favor purposeful cognition of the external reality by a pre-school child, development of its creativity and formation of its active living position. Playing space is a means of pre-school child's full-value development, manifestation of child individuality, irreplaceable companion at setting effective interactions with the social environment. It gives a preschool child a possibility to adapt to life in society and to understand and master the specificity of social interaction at the quality level.

Pre-school child's playing space organization quality must be determined through analyzing the four main components: content, material, organizational and personal.

The content component is characterized by peculiarities of playing actions and reflects the main thing, forming a playing plot. It determines a level of child's penetration in a playing situation. The psychological content of the very playing process is pre-school child's playing modeling of professional, social and interpersonal human relations and living events and situations, appearing on this base.

The material component is a filing of the playing environment with toys, specially selected materials and equipment. Objects in a qualitatively organized pre-school child's playing space must be certainly combined by functional signs according to different playing activity types. Materials and equipment must be multifunctional that is a child must have a possibility to use them differently, depending on a playing activity purpose. A playing space must consist of both components, known by a child and new, unknown, providing its cognitive development. A toy is one of most important elements of the pre-school child's playing space. It is a generalized, material, esthetic and ethic way of mastering experience of previous generations, manifestation of the social and subject world, must be mastered by a pre-school child. Toy's characteristics have the great importance not 
only for the development of psychic functions and cognitive processes, but also for the formation of the pre-school child's personality. The presence of qualities, stimulating asocial actions and feelings: violence, cruelty, aggression and indifference in a toy, is inadmissible.

The organizational component of a pre-school child's playing space consists of spatial parameters of an environment. A pre-school child's subject-playing environment must be dynamic and mobile that is a situation of free choice of actions must be modeled and motivation to its active use must be formed. It's worth underlying that a type of playing equipment placement plays an important role in a pre-school child's playing space. Pre-school child's playing space organization must be directed, in the first turn, on the development of the pre-school child's personality.

The personal component of a pre-school child's playing space is a totality of participants and ways of their joint activity in the playing process. An adult in a qualitatively organized playing space in the process of communication with a pre-school child must favor manifestations of its independence, create a possibility to communicate with coevals by own desire. At the same time an adult person must become an assistant, friend, tutor, source of development and treasury of information for a pre-school child. An adult person must have a developed ability to understand a pre-school child and all, happening with it. One of adult's main roles is creation of conditions of free choice of actions at pre-school child's playing space organization.

So, the theoretical analysis of the aforesaid problem allowed us to complexly characterize peculiarities of pre-school child's playing space organization and to offer a structural model of an organized pre-school child's playing space (Fig. 1).

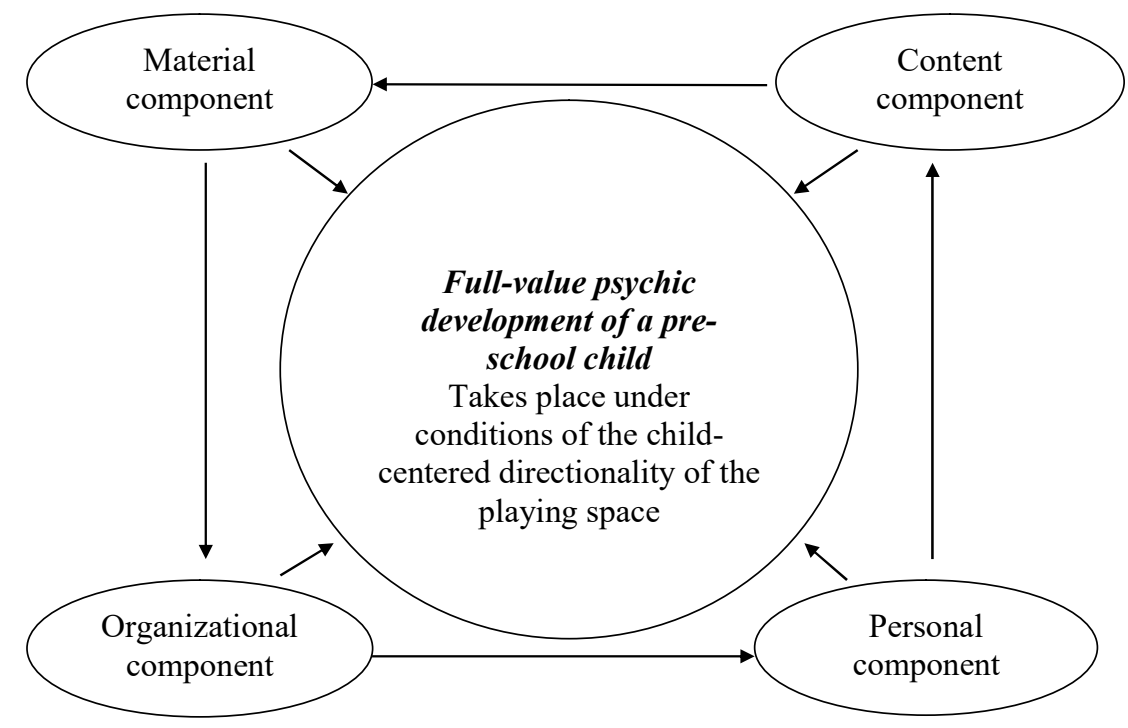

Fig. 1. Structural model of the qualitatively organized pre-school child's playing place

The offered structural model of the qualitatively organized pre-school child's playing place is based on acknowledgement of the child-centered directionality in the process of playing space organization. Such playing space construction provides the life competence establishment, revealed in a formation degree of leading activity, all activity forms and base qualities and creative interaction style, optimal for the age, grounded in the formation pre-school child's abilities to understand own possibilities, to reveal initiative and comprehensively realize oneself. Main preconditions of creating this model are an understanding of a fact that the process of pre-school child's full-value psychic development mainly depends on filling and interconnection of structural components of the playing space. The effective combination of the content, material, organizational and personal components of the playing space provides psychological safety of a pre-school child (forms trust to the world) and favors the high cooperation level in relations with others. 
Taking into account the four components (content, material, organizational, personal) and paying attention to the fact that the essential amount of children visits pre-school educational institutions, we made an attempt to estimate the quality of the pre-school children's playing space at the pre-school educational institution No. «Dzinochok» of municipal property of Zhmerynka city territorial community of the Vinnytsia region. The pre-school educational institution is for 4 groups of general education: 1 group for children of early age and 3 groups for pre-school children. Its activity is directed on education of a harmoniously developed child, creation of a favorable atmosphere, disclosing children's abilities.

The playing space quality was estimated by the method of observation over pre-school children's activity in three groups of 3-5 years old (105 children) by 4 parameters: content of realized playing actions; filling of the playing space with toys, materials and equipment, necessary for playing actions realization; dynamics and mobility of the playing space; inclusion of all children in the active playing activity.

The analysis and generalization of the obtained data demonstrate that in 54 children $(51 \%)$ realize playing actions, related to the content of human activity and senses of human relations. Preschool children give preference to plot-role games of creative character, containing enough mutually interconnected elements. We note that the active participation of children in creative games favor their consciousness development, system of needs, moral convictions and other personal qualities, essentially influencing behavior steadiness and purposefulness formation. It is worth noting that playing plots are diverse, children demonstrate initiative as to their topic and playing actions as such. At the same time, 51 studied persons (49\%) chose the productive activity, desk games, make subject actions and so on. This group of children is characterized by the absence of interest to interaction with coevals, gives priority to manipulative and uniform playing actions. The content of playing activity of this group of pre-school children is essentially depleted.

We note that filling of the playing space with different toys and equipment in all three groups is realized, taking into account thematic zones. This approach results in limits of children's choice of ways of playing actions, their initiative and reproductive type of games. It conditions the impossibility of multifunctional (variation) use of toys. It favors the choice of games on a distinctly defined topic. At the same time playing rooms lack diverse materials, games and equipment that would provide children's free choice of favorite activity types. It has been also revealed, that playing materials are renewed rarely, in average 1 time a year. It negatively reflects children's research activity.

The observation demonstrate that playing space organization is realized without taking into account the dynamics and mobility of the environment; children are deprived of a possibility to move in it freely. Such playing space doesn't develop pre-school children's skill to cooperate actively with the environment, doesn't favor the development of their activity and freedom. The groups of the pre-school educational institution lack separation of zones in active, working and relax ones. At organizing the playing space, variation, diversification and accessibility principles are observed only partially that is negatively reflected on children's mastering of skills to orient in human life and beyond it, to act rationally and moderately under new conditions.

The study demonstrate that only 59 children $(56 \%)$ show the formed motivational sphere of playing activity that is a need in playing, enough expressed playing motives of interactions with coevals and teachers. 46 studied persons (44\%) demonstrate not enough developed ability to cooperm ation, non-formed skills and absent desires to participate in common playing activity. Pre-school children of this group consider other children as pretenders to an attractive toy, but not a companion and interesting partner in activity. In such situation, the important role belongs to a teacher. But we didn't fix a situation, when a teacher behaves freely at playing, manifests artistry, amuses and interests children by own inspiration in a game. Unfortunately, the studied teachers rarely direct, support and help children in the playing activity. They have no skills of unobtrusive tactful interesting children with the playing activity. They don't understand individual features of each child. At that they don't understand that children's independent activity must not be disturbed by an obtrusive intervention of adults that may harm free development and activity of pre-school children. Educators rarely offer children games, based on partner interaction and free participation of each one. 
So, as a result of the analysis of pre-school children playing space organization and elucidation of peculiarities of its influence on their psychic development, there has been established the contradiction between the necessary (activity manifestation in playing space organization and distinct understanding of its role and importance in children's psychic development) and the real (absence of a quality activity level in playing space organization, misunderstanding of importance of its influence on pre-school children's psychic development) ideas of respondents as to its quality. Its overcoming is possible as a result of taking into account the child-centered directionality that our structured model of the playing space influence of pre-school child's psychic development is based on.

\section{Conclusions}

According to the conducted research results, it has been established that the emotional, social, intellectual and willing development of a pre-school child essentially depends on playing space organization quality. The problem of quality organization of the-school child's playing space under conditions of modern society, dictating us new rules and requirements to successful personality development becomes especially urgent. The leading condition of pre-school child's psychological development is quality playing space organization, based on the child-centered directionality. The formation of the ability to understand own possibilities, to reveal initiative and comprehensively realize themselves in pre-school children provides taking into account the filling and interconnecg tion of all structural components of the playing space. The qualitatively organized and structurally filled playing space of pre-school children will favor harmony in their psychic, physical and spiritual development. A promising direction of our further scientific studies is research of the home playing space of pre-school children.

\section{References}

[1] Vygotskii, L. S. (1991). Pedagogichekaia psikhologiia. Moscow: Pedagogika, 480.

[2] Montessori, M. (2000). Pomogi mne eto sdelat samomu. Moscow: Karapuz, 272.

[3] Frene, S. (1990). Izbrannye pedagogicheskie sochineniia. Moscow: Progress, 304.

[4] Lishchyna, S. (2017). Psykholohu DNZ: formy roboty z ditmy, batkamy, pedahohamy doshkillia. Kyiv: Shkilnyi svit, 95.

[5] Kashchuk, O. N. Spetsyfika orhanizatsii predmetno-ihrovoho seredovyshcha v konteksti sensornoho rozvytku ditei rannoho viku. Available at: http://www.ird.npu.edu.ua/files/kachyk.pdf

[6] Kononko, O. L. (2003). Komentar do Bazovoho komponenta doshkilnoi osvity v Ukraini. Kyiv, 244.

[7] Lavrentieva, H. (2001). Rozvyvalne predmetno-ihrove seredovyshche: yevropeiskyi dosvid ta novitni pidkhody. Palitra pedahoha, 4, 11-13.

[8] Petrovskii, V. A. (2003). Postroenie razvivaiuschei sredy v doshkolnom uchrezhdenii. Moscow, 211.

[9] Shteiner, R. (1993). Vospitanie rebenka s tochki zreniia dukhovnoi nauki. Moscow: Parsifal, 40.

[10] Frost, J. L. (2012). Play and child development. Upper Saddle River: Pearson, 492.

[11] Kononko, O. V. (2013). Plekaimo kulturu potreb dytyny. Doshkilne vykhovannia, 5, 2-9.

[12] Karabaieva, I. I. (2016). Osoblyvosti vyznachennia rivnia sformovanosti etychnykh instantsii u starshykh doshkilnykiv. Aktualni problemy psykholohii, IV (12), 62-74.

[13] Bekh, I. D. (2015). Zrostyty moralnu osobystist - holovna turbota. Doshkilne vykhovannia, 4, 6-8.

[14] Karasova, K. (2014). Yak navchyty ditei... hraty? Doshkilne vykhovannia, 12, 2-7.

[15] Karasova, K. V., Pirozhenko, T. (2011). Ihrovyi prostir dytyny. Kyiv: Shkilnyi svit, 128.

[16] Dauch, C., Imwalle, M., Ocasio, B., Metz, A. E. (2018). The influence of the number of toys in the environment on toddlers' play. Infant Behavior and Development, 50, 78-87. doi: http://doi.org/10.1016/j.infbeh.2017.11.005

[17] Richards, M. N., Putnick, D. L., Bornstein, M. H. (2020). Toy buying today: Considerations, information seeking, and thoughts about manufacturer suggested age. Journal of Applied Developmental Psychology, 68, doi: http://doi.org/10.1016/ j.appdev.2020.101134 